Reprod. Nutr. Dévelop., 1982, 22 (2), 379-386.

\title{
Effects of insulin, cortisol and prolactin on lipid, protein and casein syntheses in goat mammary tissue in organ culture
}

\author{
J. ŠKARDA, Eva URBANOVA, L.-M. HOUDEBINE (*), \\ C. DELOUIS $(*)$, J. BILEK
}

Institute of Animal Physiology and Genetics, Czechoslovak Academy of Sciences, 25161 Prague-Uhrineves, Czechoslovakia.

(*) Laboratoire de Physiologie de la Lactation, I.N.R.A., 78350 Jouy-en-Josas, France.

Summary. The actions of insulin, prolactin and cortisol on protein, lipid and casein syntheses were examined in goat mammary explants in culture. The synthesis of the three products was stimulated by insulin and prolactin associated or not with cortisol. Casein synthesis was stimulated only when prolactin was present in the culture medium. Prolactin alone was able to significantly support the induction of casein synthesis. After preculture in the presence of insulin alone, the tissue lost part of its capacity to respond to the prolactin stimulus but, when precultured in the presence of insulin + cortisol, it retained its total sensitivity. These data suggest that insulin, prolactin and cortisol are involved in the maintenance of goat mammary tissue in culture but that prolactin essentially stimulates milk synthesis.

\section{Introduction.}

The minimal hormonal requirements for the stimulation of mammary differentiation in vitro have been demonstrated by Elias (1959) and Barnawell (1965) ; in most species they include a combination of insulin, cortisol and prolactin. It is generally accepted that the rabbit mammary gland is more sensitive to prolactin and that a significant response can be obtained in the absence of glucocorticoids (Delouis and Denamur, 1972 ; Delouis, 1975). However, Mayne and Barry (1970) also reported that the presence of cortisol was not essential for stimulating casein synthesis in the mammary tissue of midpregnant mouse.

The present work investigates the roles of insulin, cortisol and prolactin in the differentiation of goat mammary tissue in vitro. Some of the results have already been briefly reported (Škarda et al., 1979). 


\section{Material and methods.}

$\left(U-{ }^{14} \mathrm{C}\right) \mathrm{L}$-leucine and $\left(1-{ }^{14} \mathrm{C}\right)$ sodium acetate were purchased from the Institute for Research, Production and Uses of Radioisotopes (Prague); Waymouth's tissue culture medium 752/1 (Waymouth, 1959) was a gift from the Institute of Molecular Genetics, Czechoslovak Academy of Sciences (Prague). Glucagon-free insulin was a gift from Eli. Lilly Research Laboratories (Indianapolis, Ind., USA). Ovine prolactin (NIH-P-S12 ; potency : $35 \mathrm{IU} \times \mathrm{mg}^{-1}$ ) was a gift from the National Institute of Health (Bethesda, Md., USA). Cortisol and ovalbumin were purchased from Sigma (St. Louis, Mo., USA). Mycostatin was purchased from Calbiochem AG (Lucerne, Switzerland). Penicillin potassium salt was obtained from Biotika (Czechoslovakia) and streptomycin sulphate from Medexport (USSR). Triton X-100 was purchased from Koch-Light Lab., Ltd. (Colnbrook, Bucks., England). The antibiotics and hormones were added to the medium as described earlier (Skarda et al., 1978).

Organ culture. - We used nulliparous pure-bred Czech white goats at weeks 9-11 of pregnancy and a previously-described organ culture technique (Škarda et al., 1978, 1982). Mammary explants were cultured in Waymouth's medium at $37^{\circ} \mathrm{C}$ in the presence of a constant flow of $\mathrm{O}_{2}+\mathrm{CO}_{2}(95: 5)$.

Assay for lipid synthesis. - Lipid synthesis was determined by measuring the amount of $\left(1{ }^{14} \mathrm{C}\right)$ acetate $\left(100 \mathrm{kBq} \times \mathrm{ml}^{-1}\right)$ incorporated over a 3 -h period of culture as described in Škarda et al. (1978). When the labelling period was over, the explants were removed and the lipids were extracted with $6 \mathrm{ml}$ of chloroformmethanol $(2: 1)$ in tubes sealed with plastic stoppers. The tubes, with the explants, were stored overnight at $4{ }^{\circ} \mathrm{C} ; 2.4 \mathrm{ml}$ of $2 \mathrm{p} .100 \mathrm{KH}_{2} \mathrm{PO}_{4}$ were then added and the mixture was shaken for $30 \mathrm{~min}$ on a shaker. The tubes were again left standing overnight at $4{ }^{\circ} \mathrm{C}$; the chloroform layer was then aspirated off and filtered through filter paper into scintillation vials. The filters were washed once more with chloroform. The chloroform was evaporated off, $10 \mathrm{ml}$ of SLT (Spolana, Neratovice, Czechoslovakia) were added and the radioactivity was counted.

Assays for casein and protein syntheses. - Casein and protein syntheses were determined by measuring the amount of $\left(\mathrm{U}^{14} \mathrm{C}\right)$ leucine $(100 \mathrm{kBq} \times \mathrm{ml}-1)$ incorporated over a $3-\mathrm{h}$ culture period. At the end of incubation, the explants were removed, rinsed in Waymouth's medium containing $0.155 \mathrm{mg} \times \mathrm{ml}^{-1}$ of cold L-leucine and counted and frozen until assay. Subsequently, the explants were homogenized in a glass/glass homogenizer in $0.4 \mathrm{ml}$ of phosphate buffer $10 \mathrm{mM}$ sodium phosphate, $150 \mathrm{mM} \mathrm{NaCl}$ ) containing 1 p. 100 Triton X-100, 0.5 p. 100 deoxycholate and $0.155 \mathrm{mg} \times \mathrm{ml}^{-1}$ of L-leucine (PBS-DT-AA). The homogenate was centrifuged for $20 \mathrm{~min}$ at $20000 \times \mathrm{g}$. The supernatant fluid was used for estimating both the casein and the protein synthesis.

Casein synthesis was estimated by immunoprecipitation of goat beta-casein as previously described (Houdebine and Gaye, 1975 ; Shuster et al., 1976) : $100 \mu$ l of supernatant were incubated for $1 \mathrm{~h}$ at $37^{\circ} \mathrm{C}$ and at least for $1 \mathrm{~h}$ at $4{ }^{\circ} \mathrm{C}$ with $10 \mu \mathrm{g}$ 
of crude goat casein and $200 \mu \mathrm{l}$ of sheep serum containing anti-bovine-beta-casein antibodies. The immunoprecipitate was washed 4 times by vigorous resuspension in homogenizing medium. The final pellet was dissolved in $0.5 \mathrm{M} \mathrm{NaOH}$, transferred to a scintillation vial into which $8 \mathrm{ml}$ of scintillation fluid SLT 41 (Spolana, Neratovice) - Triton X-100 (Koch-Light) (2:1) were added, and counted.

Non-specific precipitation was obtained by measuring the radioactivity absorbed on the ovalbumin/anti-ovalbumin complex (Houdebine and Gaye, 1975) formed in the presence of the supernatant. The blanks thus estimated were systematically subtracted from the estimated beta-casein/anti-beta-casein complex and the results were expressed in $\mathrm{dpm} \times \mathrm{mg}^{-1}$ tissue.

Protein synthesis was estimated by trichloroacetic acid (TCA) precipitation as follows : to $500 \mu \mathrm{l}$ of casein solution $\left(2 \mathrm{mg} \times \mathrm{ml}^{-1}\right.$ of crude casein in $0.1 \mathrm{p} .100$ $\mathrm{NaN}_{3}$ ), we added $10 \mu \mathrm{l}$ of supernatant and then $5 \mathrm{ml}$ of cold $5 \mathrm{p} .100 \mathrm{TCA}$. The mixture was left standing for $30 \mathrm{~min}$ and the precipitate was washed twice by resuspension in $5 \mathrm{p} .100$ TCA. We dissolved the dry precipitates over $10 \mathrm{~min}$ at $70^{\circ} \mathrm{C}$ in hydroxide of hyamine (Nuclear Enterprises Ltd., Sighthill, Edinburgh, Scotland) and then added $10 \mathrm{ml}$ of SLT 31 scintillation fluid (Spolana, Neratovice).

All radioactivity determinations were performed with an Isocap 300 Nuclear Chicago liquid scintillation spectrometer.

\section{Results.}

Protein, lipid and casein syntheses when hormones were added at the start of culture. - Lipid synthesis in mammary explants was estimated after 3 days of culture in the presence or absence of hormones. The results in table 1 show that

TABLE 1

Effect of insulin, cortisol and prolactin on the induction of total lipid synthesis in adipose and mammary explants from goats at week 9-10 of pregnancy

\begin{tabular}{|c|c|c|c|c|c|}
\hline \multicolumn{3}{|c|}{ Adipose tissue } & \multicolumn{3}{|c|}{ Mammary tissue } \\
\hline No horm. & $I+F+P\left({ }^{*}\right)$ & p. 100 & No horm. & $I+F+P\left({ }^{*}\right)$ & p. 100 \\
\hline $0-3 \mathrm{~h}$ & $72-75 \mathrm{~h}$ & increase & $0-3 \mathrm{~h}$ & $72-75 \mathrm{~h}$ & increase \\
\hline $257 \pm 139$ & $207 \pm 104$ & -20 & $681 \pm 49$ & $4951 \pm 792$ & +627 \\
\hline
\end{tabular}

Explants of mammary gland and mammary adipose tissue originated from the same animals. Batches of 20 explants were cultured in Waymouth's MB 752/1 medium (glucose concentration: $2 \mathrm{mg} \times \mathrm{ml}^{-1}$ ); the medium was supplemented with $4 \mathrm{mM}$ sodium acetate. Explants were exposed to $\left(\mathrm{I}^{14} \mathrm{C}\right)$ sodium acetate $\left(100 \mathrm{kBq} \times \mathrm{ml}^{-1}\right)$ for 3 -h periods of culture at the times indicated. Each value $\left(\mathrm{dpm} \times \mathrm{mg}^{-1}\right.$ tissue) is the average of the experiments (each performed in duplicate \pm SEM) on 2 goats.

(*) From the start of culture in the presence of insulin $\left(5 \mu \mathrm{g} \times \mathrm{ml}^{-1}\right)$, cortisol $\left(5 \mu \mathrm{g} \times \mathrm{ml}^{-1}\right)$ and prolactin $\left(5 \mu \mathrm{g} \times \mathrm{ml}^{-1}\right)$. 
the hormonal combination of insulin + prolactin + cortisol markedly enhanced lipid synthesis. Mammary tissue explanted from midpregnant goats contains a large amount of adipose tissue, and it was conceivable that the hormones might have stimulated the adipocytes rather than mammary epithelial cells. Cultures of adipose tissue revealed that the hormones did not modify lipid synthesis in the adipocytes (table 1).

Total mammary protein synthesis was estimated at the end of cultures performed over a 4-day period. Table 2 shows that the incorporation of ${ }^{14} \mathrm{C}$ leucine into mammary explant cytosol proteins was increased in the presence of prolactin alone. In the presence of insulin alone, the level of incorporation was higher than with prolactin alone. With cortisol and prolactin also present in various combinations with insulin, the levels of incorporation were substantially the same but higher than those with insulin alone.

${ }^{14} \mathrm{C}$-acetate incorporation into explant lipids was low in cultures without hormones and with prolactin alone; in the presence of insulin alone, this incorporation was higher. Cortisol acted synergistically with both insulin and insulin + prolactin to produce a higher level of lipid synthesis than with insulin alone or with insulin + prolactin (table 2).

TABLE 2

Effect of various hormones and hormone combinations on the levels of protein, lipid and casein synthesis in mammary explants from goats at week 10-11 of pregnancy

\begin{tabular}{|c|c|c|c|}
\hline & $\begin{array}{l}\text { Proteins } \\
\text { (4) }\end{array}$ & $\begin{array}{l}\text { Lipids } \\
\text { (3) }\end{array}$ & $\begin{array}{l}\text { Casein } \\
\text { (2) }\end{array}$ \\
\hline & \multicolumn{3}{|c|}{$\left(\mathrm{dpm} \times \mathrm{mg}^{-1}\right.$ tissue $)$} \\
\hline 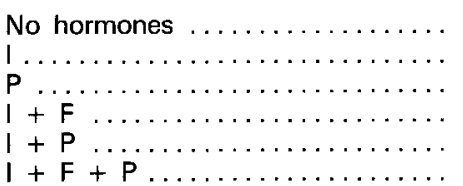 & $\begin{aligned} 5712 & \pm 999 \\
13897 & \pm 1220 \\
10466 & \pm 591 \\
26232 & \pm 488 \\
27114 & \pm 3207 \\
26107 & \pm 2606\end{aligned}$ & $\begin{array}{l}258 \pm 76 \\
3390 \pm 1320 \\
1060 \pm 244 \\
10461 \pm 1787 \\
25743 \pm 10130 \\
37822 \pm 7225\end{array}$ & $\begin{array}{c}0 \\
0 \\
533 \pm 154 \\
0 \\
1349 \stackrel{0}{ \pm} 618 \\
1445 \pm 338\end{array}$ \\
\hline
\end{tabular}

Mammary explants were exposed to $\left(\mathrm{U}^{14} \mathrm{C}\right)$ leucine $\left(100 \mathrm{kBq} \times \mathrm{ml}^{-1}\right)$ or $\left(\mathrm{I}-{ }^{14} \mathrm{C}\right)$ sodium acetate $\left(100 \mathrm{kBq} \times \mathrm{ml}^{-1}\right)$ between $96-99 \mathrm{~h}$ of culture. The values are the means of the experiments \pm SEM ; the number of goats supplying explants is shown in parenthesis. Each experiment was performed in duplicate.

Symbols : $\mathrm{I}=$ insulin $\left(5 \mu \mathrm{g} \times \mathrm{ml}^{-1}\right) ; \mathrm{P}=\operatorname{prolactin}\left(5 \mu \mathrm{g} \times \mathrm{ml}^{-1}\right) ; \mathrm{F}=$ cortisol $\left(5 \mu \mathrm{g} \times \mathrm{ml}^{-1}\right)$. Other details are given in the legend to table 1.

The level of ${ }^{14} \mathrm{C}$-leucine incorporation into beta-casein was not stimulated in either the absence of hormones or in the presence of insulin or insulin with cortisol. However, casein synthesis increased when prolactin was added alone, with insulin or with insulin and cortisol (table 2). The levels of casein synthesis were the same with insulin + prolactin and with insulin + cortisol + prolactin.

Lipid and casein syntheses when prolactin was added at $48 \mathrm{~h}$ of culture. The hormones in the above experiments were added in all cases from the 
beginning of culture. It seemed of interest to determine whether the tissue would retain its capacity to be stimulated by lactogenic hormones after a 2-day preculture. When prolactin was added to the medium $48 \mathrm{~h}$ after the beginning of culture with insulin alone, the levels of lipid, casein and protein syntheses were only increased to 35,33 and 64 p. 100 , respectively, of those when insulin + cortisol + prolactin were added at the start of culture (fig. 1).
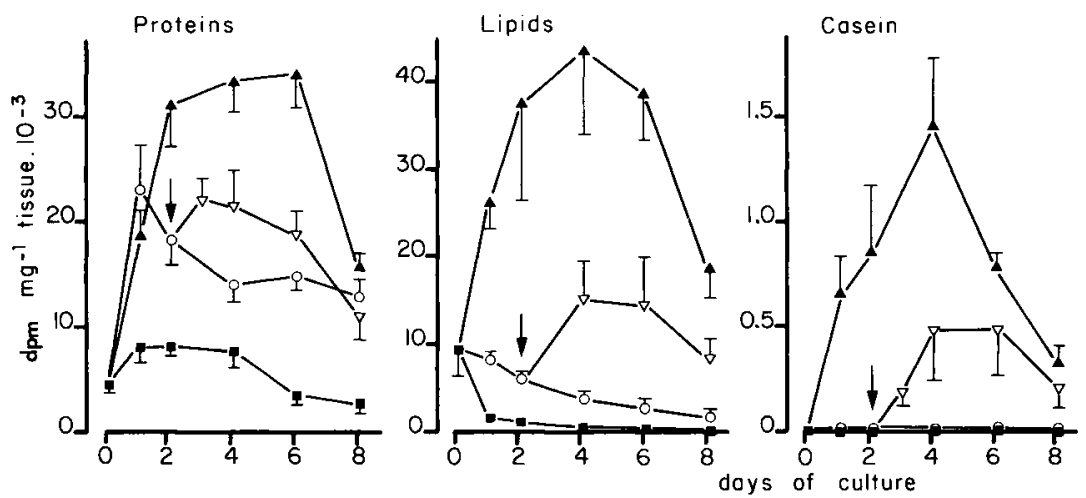

FIG. 1. - The effect on protein, lipid and casein syntheses in mammary explants from goats at weeks 10-11 of pregnancy when prolactin was added to the medium $48 \mathrm{~h}$ after the beginning of culture with insulin alone.

The values are the average of 2 experiments, each performed in duplicate \pm SEM. The arrows show the time when the insulin medium was changed to insulin + cortisol + prolactin. Other details are given in the legends of tables 1 and 2 . $\square$ : no hormone ; $\mathrm{O}-\mathrm{O}$ : insulin ; $\nabla \longrightarrow \nabla$ : insulin + prolactin ;

$\Delta$ : insulin + cortisol + prolactin.

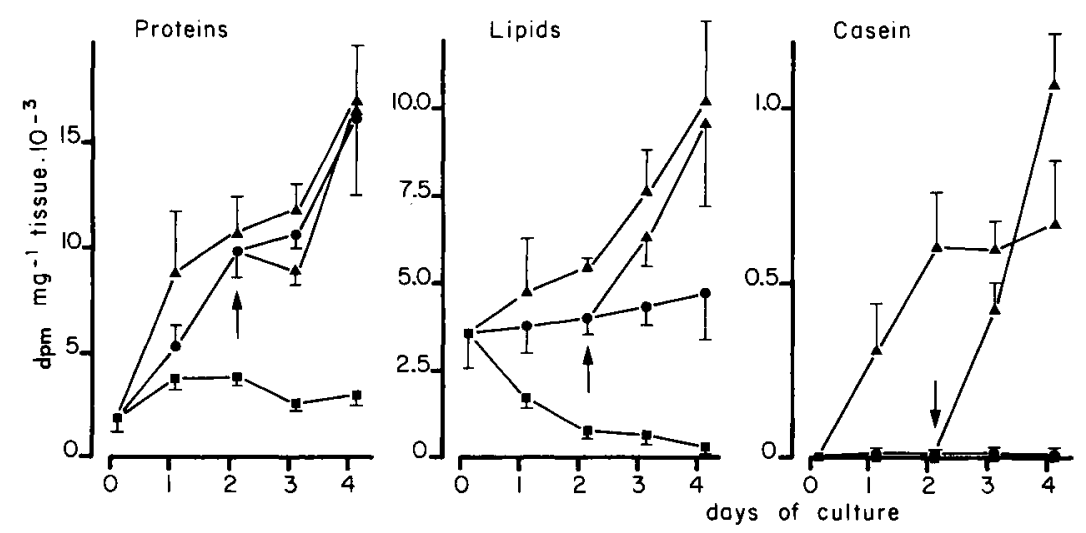

FIG. 2. - The effect of protein, lipid and casein syntheses in mammary explants from goats at weeks 10-11 of pregnancy when prolactin was added to the medium $48 \mathrm{~h}$ after the beginning of culture with insulin and cortisol.

The values are the average of 4 experiments, each performed in duplicate \pm SEM. The arrows show the time when the insulin + cortisol medium was changed to insulin + cortisol + prolactin. Details are given in the legends of tables 1 and 2.

insulin + cortisol ; : no hormones : 
The ability of prolactin to increase casein, lipid and protein syntheses was also tested on cultures performed during the first $48 \mathrm{~h}$ in the presence of insulin and cortisol (fig. 2). Under these culture conditions, the synthesis of casein, lipid and protein were highly stimulated when prolactin was added at $48 \mathrm{~h}$ of culture. The levels of protein and lipid syntheses were substantially the same between 96-99 $\mathrm{h}$ of culture (102 and 92 p. 100 respectively) as in explants cultured with insulin + cortisol + prolactin from the beginning of culture, and the level of casein synthesis under these conditions was even higher (156 p. 100) than that in explants cultured with insulin + cortisol + prolactin from the beginning of culture.

\section{Discussion.}

The results of the present work indicate that both insulin and prolactin are independently involved in the synthesis of total mammary proteins. Their effects are essentially additive, suggesting that both hormones are required to maintain mammary cell metabolism at a high level and that they act via independent mechanisms. Cortisol also seems to participate in sustaining the general activity of the mammary cell. However, this effect of the glucocorticoid is significant in the presence of insulin but not in the presence of insulin + prolactin (table 2). These observations are in agreement with previous work carried out in mouse (Ono and Oka, 1980) and rabbit (Houdebine and Djiane, 1980).

Insulin, prolactin and cortisol proved to also highly stimulate lipid synthesis in mammary explants, and it is reasonable to suppose that this phenomenon takes place in the epithelial mammary cells (tables 1,2 ). This effect may result from 2 superposed phenomena : 1) the stimulation of cellular lipid synthesis, which may be compared to the stimulation of total protein synthesis and 2) the stimulation of specific milk lipid synthesis which may be compared to the stimulation of casein synthesis. The levels of ${ }^{14} \mathrm{C}$-acetate incorporation into total lipids of mammary explants in the presence of prolactin alone never exceeded those found in the presence of insulin alone. This contrasts with the results obtained on rabbit mammary explants, in which the rates of fatty acid synthesis in the presence of prolactin alone exceeded those in the presence of insulin alone (Forsyth et al., 1972).

Although insulin and cortisol stimulated the general activity of the mammary cell, only the hormonal combination including prolactin induced casein synthesis. It is interesting to note that, even in the absence of insulin, prolactin was able to trigger casein synthesis; this agrees with previous experiments carried out on rabbit mammary explants (Devinoy et al., 1978). Insulin further stimulated casein synthesis when added with prolactin, however, relative casein synthesis was then unchanged, suggesting that the effect of insulin on casein synthesis resulted essentially from its general action on the mammary cell. Surprisingly, cortisol did not amplify prolactin action on casein synthesis, as opposed to data obtained on the mouse (Ono and Oka, 1980). In the rabbit, although cortisol potentiates prolactin action in the accumulation of casein mRNA, its action on casein 
synthesis is rather limited. Unpublished data have also shown that in sheep mammary explants and in isolated cell in culture, prolactin is quite capable of supporting an accumulation of casein mRNA in the absence of cortisol. These observations, reported in several species (Mayne and Barry, 1970 ; Forsyth et al., 1972 ; Devinoy et al., 1975 ; Ono and Oka, 1980) reinforce the idea that prolactin is the essential stimulator in the mammary gland and that glucocorticoids rather play the role of amplifiers. However, the fact that cortisol may be stored in the tissue at explantation (Bolander et al., 1979) cannot be excluded.

When precultured for 2 days in the presence of cortisol, the explants retained their full capacity to respond to the prolactin stimulus, as opposed to those precultured in the absence of that steroid. This suggests that a partial, irreversible tissue transformation took place during the preculture in the absence of the glucocorticoid. The mechanism responsible for this loss of sensitivity towards lactogenic hormones remains unknown.

Reçu en juillet 1981.

Accepté en novembre 1981.

Acknowledgements. - The authors wish to thank Dr. W. W. Bromer of the Eli Lilly Research Laboratories for providing the glucagon-free insulin and the NIAMDD, Bethesda (USA) for the gifts of prolactin.

Résumé. Les actions de l'insuline, de la prolactine et du cortisol sur la synthèse des protéines, des lipides et des caséines ont été examinées dans des explants mammaires de chèvre en culture. La synthèse de ces trois composés est stimulée par l'insuline et la prolactine associées ou non au cortisol. La synthèse des caséines n'est stimulée qu'en présence de prolactine dans le milieu de culture. La prolactine seule est capable d'induire significativement la synthèse des caséines. Après une préculture en présence d'insuline seule, le tissu a perdu une partie de sa capacité à répondre à la stimulation prolactinique. Par opposition, il garde toute sa sensibilité quand il a été précultivé en présence d'insuline et de cortisol. Ces données suggèrent que l'insuline, la prolactine et le cortisol sont impliqués dans le maintien du tissu mammaire de chèvre en culture, mais que seule la prolactine peut induire la synthèse des caséines.

\section{References}

BARNAWELL E. B., 1965. A comparative study of the response of mammary tissue from several mammalian species to hormones in vitro. J. Exp. Zool., 160, 189-206.

BOLANDER F. F., NICHOLAS K. R., TOPPER Y. J., 1979. Retention of glucocorticoid by isolated mammary tissue may complicate interpretation of results from in vitro experiments. Bioch. Biophys. Res. Comm., 91, 247-252.

DELOUIS C., 1975. Milk protein synthesis in vitro. In F. FALKNER, W. KRETCHMER, E. ROSSI, Milk and lactation. Modern problems of pediatry, vol. 15, 16-30, S. Karger, Basel.

DELOUIS C., DENAMUR R., 1972. Induction of lactose synthesis by prolactin in rabbit mammary gland explants. J. Endocr., 52, 311-319.

DEVINOY E., HOUDEBINE L.-M., DELOUIS C., 1978. Role of prolactin and glucocorticoids in the expression of casein genes in rabbit mammary gland organ culture. Bioch. biophys. Acta, $517,360-366$.

ELIAS J. J., 1959. Effect of insulin and cortisol on organ cultures of adult mouse mammary gland. Proc. Soc. exp. Biol. Med., 101, 500-502. 
FORSYTH I. A., STRONG C. R., DILS R., 1972. Interactions of insulin, corticosterone and prolactin in promoting milk-fat synthesis by mammary explants from pregnant rabbits. Biochem. J., 129, 929-935.

HOUDEBINE L.-M., GAYE P., 1975. Regulation of casein synthesis in the rabbit mammary gland. Titration of mRNA activity for casein under prolactin and progesterone treatment. Mol. cell. Endocrinol., 3, 37-55.

HOUDEBINE L.-M., DJIANE J., 1980. Effects of lysosomotropic agents and microfilament- and microtubule-disrupting drugs on the activation of casein-gene expression by prolactin in mammary gland. Mol. cell. Endocrinol., 17, 1-15.

MAYNE R., BARRY J. M., 1970. Biochemical changes during development of mouse mammary tissue in organ culture. J. Endocr., 46, 61-70.

ONO M., OKA T., 1980. The differential actions of cortisol on the accumulation of $\alpha$-lactalbumin and casein in midpregnant mouse mammary gland in culture. Cell, 19, 473-480.

SHUSTER R. C., HOUDEBINE L.-M., GAYE P., 1976. Studies on the synthesis of casein messenger RNA during pregnancy in the rabbit. Eur. J. Biochem., 71, 193-199.

ŠKȦRDA J., BILLEK J., URBANOVÁ E., 1978. Induction of lipid synthesis in mammary organ cultures from mature virgin and pregnant goats. Physiol. bohemos/ov., 27, 53-59.

ŠKARDA J., URBANOVÁ E., BÍLEK J., HOUDEBINE L.-M., DELOUIS C., 1979. Hormonal stimulation of casein synthesis in goat mammary organ culture. Physiol. bohemos/ov., 28, 278.

ŠKARDA J., URBANOVȦ E., BECKA S., HOUDEBINE L.-M., DELOUIS C., PICHOVÁ D., PICHA J., BíLEK J., 1982. The effect of bovine growth hormone on the development of goat mammary tissue in organ culture. Endocrin. exper., 16, 19-31.

WAYMOUTH C., 1959. Rapid proliferation of sublines of NCTC clone 929 (strain L) mouse cells in a simple chemically defined medium (MB 752/1). J. nat. Cancer Inst., 22, 1003-1017. 